\title{
The use of restriction fragment length polymorphisms in prenatal diagnosis of dihydropteridine reductase deficiency
}

\author{
H-H M DAHL, S WAKE, R G H COTTON, AND D M DANKS \\ From the Murdoch Institute for Research into Birth Defects, Royal Children's Hospital, Melbourne, Victoria \\ 3052, Australia.
}

SUMMARY Using a human dihydropteridine reductase (hDHPR) cDNA probe we have detected two $A v a$ II and one $M s p$ I restriction fragment length polymorphisms (RFLPs). We show that these RFLPs are in disequilibrium and calculate that approximately $60 \%$ of Caucasians are heterozygous for at least one RFLP. We demonstrate the usefulness of these RFLPs in prenatal diagnosis of DHPR deficiency in one family. This disorder can also be predicted by enzyme assays and we therefore discuss the relative merits of the two methods of prenatal diagnosis.

Progressive cerebral degeneration despite adequate dietary control of hyperphenylalaninaemia ('malignant hyperphenylalaninaemia') ${ }^{1}$ was recognised in $1974 / 5^{2-5}$ and was attributed to deficiency of the tetrahydrobiopterin $\left(\mathrm{BH}_{4}\right)$ cofactor of phenylalanine hydroxylase. Dihydropteridine reductase (DHPR) deficiency was the first enzyme defect recognised to cause this condition. ${ }^{3}$ Subsequently, other defects in the biosynthetic pathway of $\mathrm{BH}_{4}$ have been identified. ${ }^{6}$

Treatment with L-dopa and 5-hydroxytryptophan, in addition to control of phenylalanine levels by diet, seemed to give encouraging results initially, ${ }^{7}$ but the outcome has been less than satisfactory in many patients. ${ }^{8}$

DHPR deficiency is inherited as an autosomal recessive disorder. DHPR is expressed in cultured amniotic cells and in cells cultured from chorionic villus samples, so prenatal diagnosis by enzyme assay can be offered. ${ }^{9}$

At present most families who have one child affected by this condition prefer to use prenatal diagnosis and termination of pregnancy rather than to hope for a good outcome with postnatal therapy in future children.

However, it is difficult for each laboratory offering prenatal diagnosis to have available the enzyme assay required for this disease and the many other rare genetic diseases. The universality of the DNA techniques for RFLP linkage analysis makes this approach an attractive option if a DNA probe is

Received for publication 3 April 1987

Revised version accepted for publication 14 May 1987. available and if sufficient polymorphisms can be found in the DNA immediately adjacent to or in the gene.

We have reported the isolation and details of a hDHPR cDNA clone. ${ }^{10}$ The cDNA was isolated in an expression vector using antibodies against human DHPR. The amino acid sequence predicted from the cDNA matched the sequence of human DHPR peptides purified by an independent, affinity absorbent method.

Southern blot analysis of $A v a$ II digested DNA has revealed two RFLPs and another RFLP was detected with $M s p$ I digested DNA. In this paper we analyse these polymorphisms and show the usefulness of the three RFLPs for prenatal diagnosis in one family. Furthermore, we have determined the frequency of the alleles, and conclude that these three RFLPs are in linkage disequilibrium. These RFLPs are likely to be of general use in prenatal diagnosis of DHPR deficiency.

\section{Methods}

Cultured fibroblasts or transformed lymphoblast cell lines obtained from four members of family A were

TABLE RFLPs linked to human dihydropteridine reductase.

\begin{tabular}{llll}
\hline $\begin{array}{l}\text { Restriction } \\
\text { endonuclease }\end{array}$ & $\begin{array}{l}\text { No of } \\
\text { alleles }\end{array}$ & $\begin{array}{l}\text { Size of } \\
\text { alleles }(\mathrm{kb})\end{array}$ & $\begin{array}{l}\text { Frequency of } \\
\text { alleles }\end{array}$ \\
\hline AvaII & 2 & $9 \cdot 0 / 7 \cdot 0$ & $0 \cdot 66 / 0 \cdot 34$ \\
AvaII & 2 & $5 \cdot 7 / 4 \cdot 3$ & $0 \cdot 26 / 0 \cdot 74$ \\
MspI & 2 & $1 \cdot 3 / 1 \cdot 2$ & $0 \cdot 63 / 0 \cdot 37$ \\
\hline
\end{tabular}




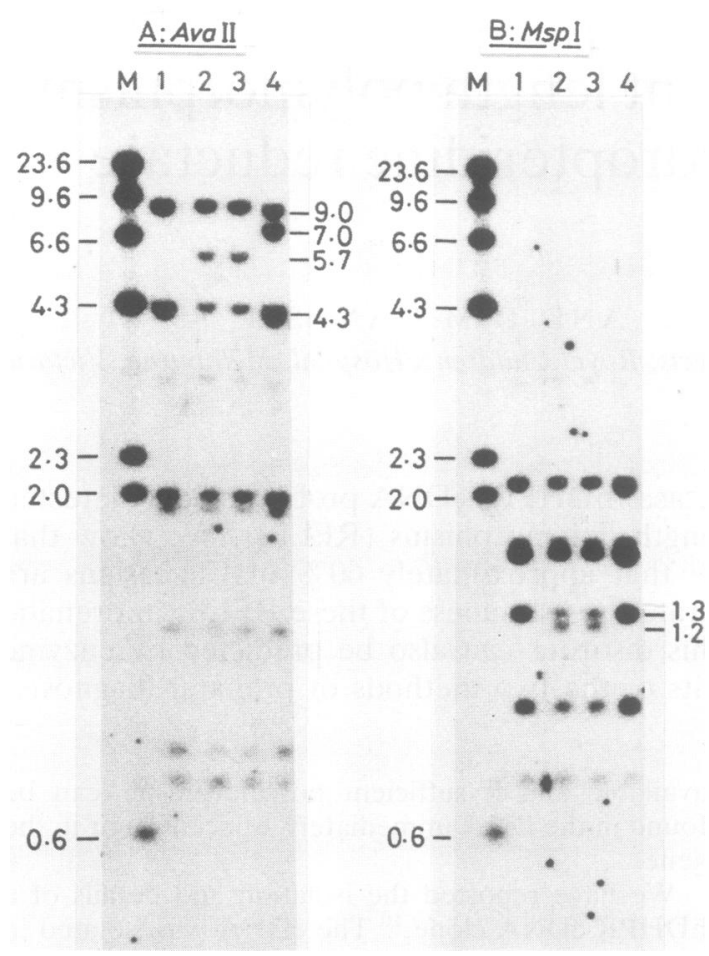

FIG 1 RFLP analysis of family $A$ using a hDHPR $c D N A$ probe. In panel $A$ the chromosomal DNA has been digested with Avall and in panel B with MspI. Lane 1: affected child 1, lane 2: child 2, lane 3: father, lane 4: mother.

the source of chromosomal DNA. These family members were the parents, a child with DHPR deficiency (child 1), and a fetus of unknown DHPR status evaluated prenatally ${ }^{9}$ (child 2 ). To estimate the frequency of the RFLPs, blood was obtained from 42 unrelated Caucasians and lymphocytes were isolated. Ten fibroblast cell lines from patients with DHPR deficiency were the source of the patient material. DNA was prepared from the cells, ${ }^{11}$ digested with restriction endonucleases $A v a$ II or MspI, electrophoresed on $0.7 \%$ agarose gels, and blotted onto Gene Screen Plus membranes (New England Nuclear). The blots were hybridised at $42^{\circ} \mathrm{C}$ to oligonucleotide labelled hDHRP cDNA fragments ${ }^{12}$ according to manufacturer's recommendations.

\section{Results}

The hDHPR cDNA probe recognises two $A v a \mathrm{II}$ and one MspI polymorphisms (table). Southern blot analysis of the DNA from family $A$ is shown in fig 1 .
The Avall digested DNA (panel A) shows the presence of four different bands (at $4 \cdot 3,5 \cdot 7,7 \cdot 0, \stackrel{D}{\rightarrow}$ and $9.0 \mathrm{~kb}$ ). From these data it was concluded thato the $4.3 \mathrm{~kb}$ and $5.7 \mathrm{~kb}$ bands are allelic, as are the 7.0 을 and $9.0 \mathrm{~kb}$ bands. This family also shows the $1.2 / 1.3 \frac{\bar{m}}{7}$ kb RFLP, obtained after digestion with MspI (fig 1, panel B).

Fig 1 also shows that this family is informative with these RFLPs, and that they can be used in. prenatal diagnosis of DHPR deficiency. The $\overrightarrow{\vec{\omega}}$ affected child (fig 1A, lane 1) is homozygous for the $\stackrel{\circ}{\circ}$ $9.0 \mathrm{~kb}$ and $4.3 \mathrm{~kb}$ alleles and the mutation(s) must $\overline{3}$ be associated with the $9 \cdot 0 / 4 \cdot 3 \mathrm{~kb}$ allelic configuration, as summarised in fig 2 . The data indicate that $\mathrm{G}$ child 2.(fig $1 \mathrm{~A}$, lane 2 ) is a carrier of the condition. $\overrightarrow{\text { }}$ This conclusion is in agreement with the MspI digest or data (fig 1B). With this enzyme the affected child 음 (lane 1) is homozygous for the $1.3 \mathrm{~kb}$ allele and the mutation must segregate with this allele. Child 2 is heterozygous for the polymorphism and is therefore $\vec{c}$ not affected. However, because the mother is homozygous for the $1.3 \mathrm{~kb}$ allele (lane 4 ), it is not possible to determine from the MspI RFLP pattern $\bigodot_{\infty}$ whether child 2 is a carrier or homozygous normal. ${ }^{\infty}$

Analysis of allele frequencies in 42 unrelated, 마 unaffected Caucasians has shown evidence for link-乏 age disequilibrium between the polymorphisms. The frequency of people heterozygous for one or more of the DHPR RFLPs was found to be $60 \%$ in the $\mathbb{Q}^{\mathbb{Q}}$ normal population, while the expected frequency $\underset{\Rightarrow}{\overrightarrow{2}}$ based on complete linkage equilibrium between the $\frac{3}{3}$ three RFLPs would have been $80 \%$. Identification of further RFLPs both within or linked to the DHPR gene will increase the proportion of informative families.

Analyses of the limited number of DNA samples:

\section{Family A \\ Avall:}

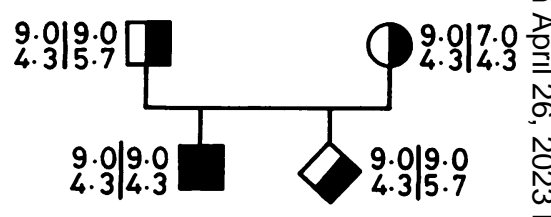

Mspl:

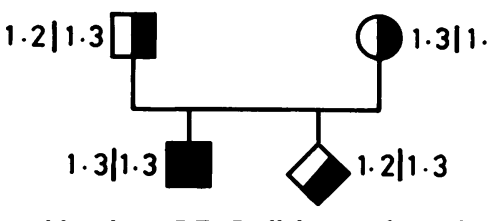

FIG 2 Pedigree of family A. RFLP alleles are shown by reference to band sizes in fig 1 . 
suggest that the $9 \cdot 0 / 5 \cdot 7 / 1 \cdot 2$ and $7 \cdot 0 / 4 \cdot 3 / 1 \cdot 3$ haplotypes may be over-represented in the unaffected group and that the $7 \cdot 0 / 5 \cdot 7 / 1 \cdot 2$ haplotype appears to be found frequently in the DHPR deficient cases studied so far. Detailed family studies would need to be undertaken to confirm this finding and to establish the frequency of the DHPR haplotypes in both the normal and DHPR deficient populations. However, it is clear from our data that DHPR deficiency is not tightly associated with specific RFLP haplotypes.

\section{Discussion}

Prenatal diagnosis with termination of an affected fetus is currently used by most couples who have had one child with an inborn error of metabolism for which treatment is imperfect, leaving serious residual defects. Many of these conditions are rare. When available, the assay for the enzyme concerned is specific and each requires careful standardisation in amniotic cells before prenatal testing can be offered. It is therefore difficult to make testing for each rare disease available at every genetic centre. Either each centre has to develop and maintain expertise with a large number of enzyme assays, or else samples have to be shipped to one of a small number of centres specialising in that particular enzyme assay.

Using recombinant DNA technology it should be possible to establish tests which are technically similar for every disease, so that each laboratory could have a full array of capabilities just by possessing the appropriate DNA probes. In the future, stable, non-radioactive probes may further simplify this approach. As the appropriate probes become available the relative merits of DNA and enzyme assay approaches should be evaluated for each inborn error of metabolism.

Direct identification of the mutation in the gene is not yet a practical approach to prenatal diagnosis for most genetic diseases, because most mutations are single base substitutions and detection of these is very laborious. Exceptions do exist, for example, the frequent gene deletions seen in $\alpha$ thalassaemia. Southern gel analysis of DNA from 11 patients with DHPR deficiency did not reveal any with a gene deletion. ${ }^{10}$ One of the 11 patients did lack detectable DHPR mRNA. ${ }^{10}$ In previous immunochemical studies of DHPR protein, the presence of antibody cross reacting material (CRM) in patients was assessed. ${ }^{13}{ }^{14}$ Together, these results indicate heterogeneity within DHPR mutations with at least three classes: CRM positive, CRM negative/mRNA positive, and CRM negative/mRNA negative. The number of patients available is not sufficient to determine whether there is tight linkage of a specific haplotype to any of these groups.

Potentially, DNA linkage to RFLP polymorphisms can be applied to all cloned genes. The power of this technique depends upon the number of useful RFLPs that can be found in the vicinity of the gene, in order to increase the chances of the RFLP analysis being informative in a specific family. Even the limited studies performed to date with just seven enzymes have revealed three RFLPs in the human DHPR gene. AvaII has revealed two polymorphic sites and MspI has revealed a further site. These have been used in analysing a family which had presented for prenatal diagnosis. The diagnosis had already been defined as unaffected, probably heterozygous, by enzyme assay. ${ }^{9}$ The RFLP data could have been used to reach this conclusion, defining the heterozygous state of the fetus with greater confidence. These RFLPs should be useful for prenatal diagnosis in affected families. Tests with other restriction enzymes have revealed further RFLPs which are still being analysed by family studies.

It is clear that DHPR deficiency is an inborn error of metabolism for which it will be possible to offer prenatal diagnosis by RFLP linkage in the majority of families. This method of prenatal diagnosis may become preferable to enzyme assay, depending upon the way in which the organisation of these services moves in the future.

Furthermore, the DHPR gene has been localised to band $\mathrm{p} 15.3$ on chromosome 4 by in situ hybridisation to metaphase chromosomes (R M Brown and H-H Dahl, submitted for publication). RFLPs in the DHPR gene region might, therefore, also prove useful in linkage studies to Huntington's disease.

\section{References}

' Danks DM, Bartholome K, Clayton BE, et al. Malignant hyperphenylalaninaemia-current status (June 1977). J Inher Metab Dis 1978;1:49-54.

2 Smith I, Clayton BF, Wolff $\mathrm{OH}$. New variant of phenylketonuria with progressive neurological illness unresponsive to phenylalanine restriction. Lancet 1975;i:1108-11.

${ }^{3}$ Kaufman S, Holtzman NA, Milstein S, Butler IJ, Krumholz A. Phenylketonuria due to a deficiency of dihydropteridine reductase. N Engl J Med 1975;293:785-90.

4 Bartholome K. A new molecular defect in phenylketonuria. Lancet 1974;ii: 1580 .

5 Danks DM, Cotton RGHC, Schlesinger P. Tetrahydrobiopterin treatment of variant form of phenylketonuria. Lancet 1975;ii: 1043.

6 Niederwieser A, Ponzone A, Curtius HC. Differential diagnosis of tetrahydrobiopterin deficiency. $J$ Inher Metab Dis 1985;8(suppl 1):34-8.

7 Bartholome K, Byrd DJ. L-dopa and 5-hydroxy-tryptophan therapy in phenylketonuria with normal phenylalaninehydroxylase activity. Lancet 1975;ii:1042-3.

${ }^{8}$ Smith I, Hyland K, Kendall B, Leeming R. Clinical role of pteridine therapy in tetrahydrobiopterin deficiency. $J$ Inher Metab Dis 1985;8(suppl 1):39-45. 
" Firgaira FA, Cotton RGH, Danks DM, Fowler K, Lipson A, Yu JS. Prenatal determination of dihydropteridine reductase in a normal fetus at risk for malignant hyperphenylalaninaemia. Prenat Diagn 1983;3:7-11.

10 Dahl HHM, Hutchison W, McAdam W, Wake S, Morgan FJ, Cotton RGH. Human dihydropteridine reductase: characterisation of a cDNA clone and its use in analysis of patients with dihydropteridine reductase deficiency. Nucl Acids Res 1987;15:1921-32.

11 Weeks DP, Beerman N, Griffith OM. A small-scale five-hour procedure for isolating multiple samples of CsCl-purified DNA: application to isolations from mammalian, insect, higher plant, algal, yeast and bacterial sources. Anal Biochem 1986;152: 376-85.

${ }^{12}$ Feinberg AP, Vogelstein B. A technique for radiolabelling
DNA restriction endonuclease fragments to high specific activ ity. Anal Biochem 1983;132:6-13.

${ }^{13}$ Firgaira FA, Choo KH, Cotton RGH, Danks DM. Hetero geneity of the molecular defect in human dihydropteridi reductase deficiency. Biochem $J$ 1981;193:677-82.

14 Cotton RGH, Jennings IG, Bracco G, Ponzone A, Guard商 magna $O$. Tetrahydrobiopterin non-responsiveness dihydropteridine reductase deficiency is associated with the presence of mutant protein. J Inher Metab Dis 1986;9:239-430

Correspondence and requests for reprints to $\overrightarrow{D P}$ H-H M Dahl, Murdoch Institute for Research int $\vec{\theta}$ Birth Defects, Royal Children's Hospital, Mefw bourne, Victoria 3052, Australia. 